Marquette University

e-Publications@Marquette

$12-1-2008$

\title{
Who Could Best Complement a Team of Family Business Researchers - Scholars Down the Hall or in Another Building?
}

Alex Stewart

Marquette University, alex.stewart@marquette.edu

Post-print.

Family Business Review, Volume 21, No. 4 (December 2008), DOI. 


\title{
Who Could Best Complement a Team of Family Business Researchers-Scholars Down the Hall or in Another Building?
}

Alex Stewart

\begin{abstract}
This study explores which fields might potentially collaborate in family business research. It compares 14 research fields for their structure of topical attention. The most convenient collaborations, such as those between entrepreneurship, family business, and strategy researchers, prove to be the most appropriate for some research purposes. However, less common collaborations, particularly with scholars from law, history, and anthropology, appear to be the most appropriate for other projects. Family and marital therapy prove to be a less promising collaborator than one might expect because of their strong skewing to familial rather than commercial topics. Correspondingly, entrepreneurship also proves to be an outlier field, skewed to the commercial rather than the familial, with surprisingly little in common with the topical interests of family business researchers.
\end{abstract}

\section{Introduction}

Let's say that you want to conduct a study of the role of distrust and secrecy in family business succession. You suspect that scholars trained in some other disciplines might make for good collaborators but you do not know who would be most helpful. Do you venture across campus or do you take the familiar trek down the halls of your own department? This study explores which scholarly fields might offer the most productive collaborations and, in so doing, suggests that there are times when venturing across campus could be the most fruitful.

Just as an idea is "interesting" if it incorporates both the familiar and the new (Davis, 1971), collaborations are productive if they both share common ground and intellectual resources that are complementary rather than duplicated (Epstein, 2005, pp. 257-258). For example, scholars in history, law, and anthropology will bring knowledge of literatures, theories, and research methods that differ from those of most management scholars. To be collaborators, of course, scholars must also share a "mutual interest" (Epstein, 2005, p. 256). Moreover, this mutual interest must be rather specific. An interest in family business succession is too broad a basis for the hypothetical study that also incorporates secrecy and distrust. Therefore, to explore which scholarly fields are in general complementary we need to know the structure of 
their attention to topics, that is, the extent to which attention to one topic leads to attention to other topics.

The field of study that allows us to map the structure of topical attention is bibliometric research, which is the application of quantitative analysis to data sets comprised of publications. Using methods such as co-citation and co-word analysis, it offers a "map [of] the intellectual structure of research" (Ramos-Rodríguez \& Ruíz-Navarro, 2004, p. 982). Thanks to the study by Casillas and Acedo (2007), we start to see a map for the family business field. The "Special Issue on Understanding Entrepreneurship Scholarship from a Bibliometric Perspective" (Entrepreneurship Theory and Practice, May 2006) draws a map for the entrepreneurship field. These maps show "how...scholarship is organized" (Gartner, Davidsson, \& Zahra, 2006, p. 321, emphasis added). Bibliometry has studied who does but not who might collaborate.

\section{Bibliometry and the Structure of Scholarship}

The capacity to map the structure of potential collaboration matters because the complexity of the social organization of research makes this topical structure nonobvious. The visible and formally organized units, such as departments and disciplines, are far from homogenous but, instead, are "congeries" of distinct research interests (Campbell, 1969). Not that they do not matter; "disciplines" may be "arbitrary hodge-podges" rather than the homogenous, enduring communities of thought that they present to the world, but they do attach themselves to the social units—departments—-that provide social identity and strongly affect career opportunities (Campbell, 1969, pp. 331-332; also Abbott, 1988, p. 56; Adams, 1988, pp. 167-168, 185; Henkel, 2004). In Dogan's (1997, p. 430) estimation, "in the social sciences there are today...between ten and fifteen formal disciplines, but hundreds of specialties" and other smaller categories. In a stylized model of academic organization (Hargens, 2000), two other levels of organization comprise the disciplines. After disciplines, the next largest units are "specialties," with their own "formal organizations...journals and scientific societies" (Hargens, 2000). Examples include family business, entrepreneurship, and strategic management. Within specialties are "research areas," which typically have "fewer than 50 active participants" and considerable flux in membership (Hargens, 2000). Examples include corporate governance and the performance effects of family control.

One reason that the social organization of research is complex is that the informal structure of the smaller categories does not map neatly onto the formal organization of the larger ones. Research areas may not be contained by one and only one specialty, and specialties may not all be contained by one and only one discipline. For example, research

\section{Stewart}


programs on the performance implications of family ownership could affiliate with one or a number of specialties, such as entrepreneurship, family business, and strategic management. They could also affiliate with disciplines other than management, such as economics or finance.

Cross-fertilization of this sort does occur, but many scholars restrict their collaborations to those that are organizationally convenient. Closely related research programs in other fields may simply remain unaware of one another (Callon, Courtial, Turner, \& Bauin, 1983; Campbell, 1969; Zald, 2002). Ignorance of related scholarly communities has been detected within entrepreneurship (Gartner et al., 2006; Grégoire, Noël, Déry, \& Béchard, 2006; Reader \& Watkins, 2006). We can assume the same for family business, in which many scholars are unacquainted with relevant studies in anthropology (Jones, 2005; Stewart, 2003).

There are two ways bridges could be made across fields. One would be for scholars to learn enough about other fields that they could cite other literatures. This is very difficult (Devons \& Gluckman, 1964) and it tends not to occur. For example, in recent randomly selected issues of Entrepreneurship Theory and Practice (ET\&P) (31(5)), Family Business Review (FBR) (20(3)), Journal of Business Venturing (JBV) (23(1)), and Strategic Management Journal (SMJ) (28(4)), there were 995 citations to journals but no citations to journals in anthropology, five to journals in family and marital therapy, and six to journals in law.

The second approach to bridging across fields is interdisciplinary teams. This is rare, judging by the employing departments of authors in leading specialty journals, which fall within a limited set. For example, departmental affiliations for authors in FBR, and related journals such as $E T \& P$ and JBV, include few outside "management" (or departments of similar names). Moreover, in the 2006 and 2007 volumes of FBR there were no affiliations with anthropology, history, law, public administration/policy, or sociology departments.

Scholars who are aware of the value of cross-fertilization might choose not to attempt it. Multispecialty teams can challenge a scholar's sense of competence, provoking anxiety (Devons \& Gluckman, 1964; Zerubavel, 1995). Multidisciplinary research is challenging due to power and status differentials, discrepant norms of methodology and publication, and terminological confusion (Klein, 2005; O’Donnell \& Derry, 2005). Further, the sociopolitical context for academic units favors the more homogenous groups (Hambrick \& Chen, 2008). This is a reason some scholars conceive of their specialties as a "more or less distinct field...develop[ing] unique theory... and defending the area's boundaries" (Meyer, 1991, pp. 822-823).

By contrast, other scholars conceive of their specialties as topical forums that should draw on whatever intellectual traditions are appropriate (Campbell, 1969, pp. 335-336; Meyer,

\section{Stewart}


1991; Stewart, 1995). This approach is manifested by the ongoing "fragmentation and hybridization" of research (Dogan, 1997). It is most advanced in engineering and applied sciences but is well advanced in some social sciences (Callon et al., 1983; Henkel, 2004; Morillo, Bordons, \& Gómez, 2003). Although its traces are found in the "interdisciplinary" history of strategy (Meyer, 1991, p. 830), it may be that management fields have seen rather more fragmentation and less recombination or hybridization than other fields (Grégoire et al., 2006).

Family business and entrepreneurship are for their part fragmented, with several "different partially competing groups, or clans" and no "overarching theme" to be found (Baker \& Pollock, 2007, p. 307; Gartner et al., 2006, p. 323 for quotes; see also Casillas \& Acedo, 2007). Fragmentation could be ecologically useful by providing variation, but it would be most fruitful if it would also form the basis for recombination across fields. Competence-crossing scholarship generates innovation by providing access to other modes of thought, other attack skills and methods, and other literatures and findings (Thagard, 2005). As a result, it is favored by funders of applied research (Shugan, 2003; Small, 1999). For example, the first "investment priority" in the National Science Foundation's (NSF's) current strategic plan (NSF, 2006, p. 6) is to "promote transformational interdisciplinary research."

Family business currently faces the challenge of seeking legitimacy and resources, associated with disciplines and departments, while attempting to offer useful research, associated with multispecialty and multidisciplinary research. Family business is thus pulled in two directions just as strategy was earlier (Meyer, 1991): toward well-defined boundaries and uniqueness but also toward a pluralistic arena for engaging important research questions. This tension is reflected in essays on how best to legitimize and stabilize the field (Bird, Welsch, Astrachan, \& Pistrui, 2002; Brockhaus, 1994; Dyer \& Handler, 1994; Hoy \& Verser, 1994; Sharma, 2004; Zahra \& Sharma, 2004).

\section{Method}

\section{A Variant of Co-Word Analysis}

As Gartner and colleagues wrote about entrepreneurship, "we hope that scholars...may look beyond their immediate cluster of interest to the many different themes/groups" that might prove relevant (Gartner et al., 2006, p. 327). Bibliometry can be a useful tool for identifying potential linkages because it can find which fields have related structures of attention to topics of interest. However, to do so requires methodological innovation (Schildt, Zahra, \& Sillanpää, 2006). Bibliometric maps to date have restricted themselves to revealing actual but not potential invisible colleges (Ellis, Allen, \& Wilson, 1999). They have recorded manifest topics contained in

\section{Stewart}


article titles, key words, or abstracts (Griffiths \& Steyvers, 2004; He, 1999). Often, they have covered a small number of highly cited articles or a handful of journals, presenting the danger of arbitrariness, given the practice of authors to publish in journals from multiple disciplines (Bedeian, 2005; Pierce, 1999).

For our purposes, the approach in conventional bibliometry that is most nearly well suited is co-word analysis or "shared-vocabulary" analysis (Small, 1999, p. 73). However, there are two limitations in looking for shared topics based on the co-occurrence of word dyads (He, 1999). One is that words are not topics. If we measure topics by words, we need to avoid truncated sets of words, especially as different fields may use different words for similar topics. The danger is analogous to the "concordance fixation" in literary studies (Slingerland, 2003, p. 11), in which shared meanings or topics are missed because of the wide range of words or sets of words that can refer to the same topic. The second limitation is that co-word analysis has been used to measure the structure of concepts with precisely shared terms rather than to compare the structure across fields that use different terminology (He, 1999). However, there is nothing in the approach that prevents this because we can search for alternative words that might be used for the same (or similar) topics. The solution, contrary to established usage (Callon et al., 1983, Jacobs, 2002; Teil \& Latour, 1995), is to create search strings with the operator "or."

\section{Data}

With our goal of exploring topical attention across multiple fields with multiple topics it is important to have a robust data set. Fortunately, this is available in many research libraries: the complete set of databases in the ProQuest ${ }^{\circledR}$ Research Library search engine of journal articles ("scholarly" journals only). This data set is very large, as can be seen in the number of articles, for example, more than 200,000 in one of the research fields. Some searches result in a large number of articles, with the largest being 13,594 for the co-occurrence of kinship and secrecy within history; conflict and secrecy within law is nearly as large at 13,420. Using such a large database is appropriate when searching for potential collaborators, but it generates different results than restricting it to a small number of "top" journals (as in Lockett \& McWilliams, 2005). Another qualification about this data set is that, as with virtually all bibliometry, it includes only one type of publication, the journal article, whereas other types of writings, such as books, are known to be important (Callon et al., 1983; Reader \& Watkins, 2006).

\section{Topics Covered}

\section{Stewart}


Topics were chosen so as to broadly represent key interests of family business and entrepreneurship researchers and to include among these those topics that might be shared by a wider set of fields. They were also chosen so as to be evenly divided, with eight each, between terms that are relatively more oriented to the familial or to the commercial poles. The familial eight are affines (relatives by marriage), conflict, distrust (because trust is an ambiguous search term that often refers to the financial instrument), emotion, kinship, posterity, secrecy, and succession; the commercial eight are alertness, brokerage, entrepreneurial opportunity, innovation, planning, private equity, profit, and venturing.

The division between terms that are relatively more oriented toward the familial or the commercial reflects globally observed dichotomies such as private/public, informal/formal, nature/culture, family/polity, and female/male (Comaroff, 1987; Jones, 2005). The way these antinomies play out varies across cultures, and simply assuming their relevance can conceal relationships between kinship and social power (Harrell, 1997; McKinnon, 2000; Yanagisako, 1987). The poles are best viewed as purely analytical domains that are interconnected in practice (Fortes, 1969, pp. 63, 97, 99). With these qualifications in mind, it is likely that scholarly fields gravitate more strongly to one pole or the other, particularly in the topics they flag in their abstracts in contrast with full texts. Even anthropologists have been taken to task for excessive concern for the politicojural rather than domestic domains (Carsten, 2000, pp. 17-18; Holy, 1996, p. 51; this latter dichotomy derives from Fortes, 1969, pp. 63, 79, 95-100, 110, 232). Moreover, the domestic-public distinction is most pronounced in modern capitalist society (Fortes, 1969, p. 79; Harrell, 1997). Therefore, we might expect disciplines that focus on capitalism, such as entrepreneurship, finance, and strategy, to gravitate toward the commercial pole and even to regard the familial as a stigmatized topic (Dyer, 2003). Family business would be expected to be balanced and the nonbusiness fields to gravitate toward the familial pole.

For selecting the two sets of eight topics the primary source was a broad reading of the interdisciplinary literature in family business and entrepreneurship and reviews such as Sharma (2004) and bibliometric research such as Casillas and Acedo (2007). This set of topics is not definitive-no such set of topics exists—but it is meant to be sufficiently broad and representative for our purposes. At the risk of stating the obvious, the use of these topics implies that this is not a study of the structure of topical attention in general, but a study of the structure of attention to 16 topics that are of interest to two of these fields. If other fields had been the centers of interest, other topics would have been chosen.

\section{Search Words and Subjects to Represent Topics}

\section{Stewart}


The selection of words to represent these topics proved to be more difficult than the selection of topics themselves. Even more than the topics, the words needed to be developed iteratively with multiple runs of the searches. With such a large data set it is not feasible to track down all possible terms and their meanings in context; rather, it was necessary to begin with a thesaurus and a preliminary set of terms and seek both to add other words that appeared in the searches and to weed out words that were used either metaphorically (e.g., "child," "family," "parent," or "generation") or were literally used but misleading (e.g., "Wiley and Sons"). As these examples suggest, many kinship terms have these properties. Both academic jargon and everyday terms were used, for example, in the set of terms related to brokerage.

An example of the iterative development of the terms is the use of terms drawn from different fields, such as terms for brokerage drawn from Austrian economics on arbitrage (e.g., Kirzner, [1997] 2000), from anthropology on spheres of exchange (Barth, 1967), and sociology on structural holes (Burt, 1992) (for the role of these topics in entrepreneurship, see Grégoire et al., 2006). Some topics initially derived from particular writings, such as the derivations of secrecy from Marcus and Hall (1992); this proved to be a widely noted topic. Posterity derived from Miller and Le Breton-Miller (2005), and while it proved less widely noticed it appears to have theoretical potential (Nicholson, 2008). These are illustrations of the judgments needed, but judgments are always required even with more established approaches such as co-citation analysis (Reader \& Watkins, 2006).

The search words, as they developed, were used for searches within ProQuest subjects, within article abstracts, and within full texts. This latter distinction permits the distinction between a tight and a loose measure of topical co-occurrence. If topics co-occur in an abstract, we can assume that they are somewhat associated in the writer's mind. If they co-occur only in the text, this might or might not be the case. Moreover, scholars who gravitate toward the commercial rather than family pole, for example, might find that the realities of their data lead them to pay more attention to the other pole. For example, scholars who view topics from the familial domain, such as emotion or secrecy, as outside the purview of serious business researchers might find that the firms that the study can be understood only when their embeddedness in kinship is considered (Aldrich \& Cliff, 2003; Anderson, Jack, \& Dodd, 2005). The reverse could also hold, with family therapists finding that the conflicts they seek to redress have their origins in disputes about business succession. The expectation is that fields that gravitate to one pole strongly in the abstracts will do so less strongly in the text, and vice versa. The distinction between abstracts and text also lets us see if a topic's prominence in the abstracts is much greater than in the text, in which case the topic may perform a ceremonial framing function.

\section{Stewart}




\section{Subject-based searches}

The limitations of the word-based search-possible idiosyncrasies based on either the metaphorical uses of terms or the limitations of the selected terms-are counterbalanced with subject-based searches within ProQuest. Subject searches have the twin benefits of using preexisting terms that are in that sense objective (Callon et al., 1983) and of being based on coding by ProQuest staff of all the articles directly. The limitations are twofold as well. ProQuest subjects can fail to include the topics of interest, either completely or partially. ProQuest's "Controlled Vocabulary of Subject Terms" (http://www.il.proquest.com/products_pq /controlled-vocab/PQSUBJ.pdf) completely misses affine, conjugal, and in-law (terms concerning relatives by marriage), as well as both descendant and posterity. Neither trust nor distrust are searchable. Subjects can also be idiosyncratic, particularly in the coding of articles as belonging to the fields of marketing and organizational behavior, fields with very broad mandates as coded by ProQuest. Despite these limitations, all subject-based searches use the ProQuest subject category to determine the field of study as well as the topics.

For abstract and text-based searches, the field of study was determined by journal of publication (based on iterative searches and Ulrich's Periodicals Directory). The advantage of this approach (used also by Casillas \& Acedo, 2007 and Grégoire et al., 2006 for single journals) is that we can assume that if authors choose to publish within a field-based venue, they are affiliating that particular article with the field in question. The alternative sometimes used (e.g., Cornelius, Landström, \& Persson, 2006) of determining the field by words in the title, keywords, or abstract has the disadvantage that this affiliation may well be spurious; it is quite possible to refer to another field without being associated with it oneself. It must be admitted that disadvantages of using the venue for this purpose are that general-purpose journals, such as the Academy of Management's journals, cannot be used, and some fields, such as organization theory, lack a journal uniquely devoted to their field. For the full set of topics and terms used, both for subject and abstract and text searches, and the sample sizes, please see Table 1. (Sample sizes refer to the sum of co-occurrences, measured by degree centrality, across all scholarly fields.)

\section{Scholarly Fields Included in the Study}

Fourteen fields were included in the study (Table 2). Most obviously related to family business (in journals and Academy of Management organization) is entrepreneurship, and from there strategy was an easy choice due to historical and organizational connections (Baker \& Pollock, 2007; McCarthy \& Nicholls-Nixon, 2001). Public administration and policy was included

\section{Stewart}


for its formative influence on strategy, for example, in the area of emergent planning. Other fields were added as candidates for collaboration within business schools (such as finance and marketing), or as nonbusiness disciplines that have impacted business scholarship (such as economics, psychology, and sociology). Three others were added for specific expertise relevant to family business. Anthropology was added for expertise in kinship studies, family and marital therapy for the impact and treatment of personality disorders within families, and law for estate planning and trusts and general business law.

Because this study is exploratory-it seeks to discover something of interest that has not yet been detected-it lacks a theoretical foundation for true hypotheses. That is not to say that it lacks expectations or that any and all findings would be interesting. It is expected that these 14 fields will be distinct in their topical attention such that some fields would bring diversity to a team but also overlapping sufficiently that collaboration might be fruitful. This would be consistent with the literature cited on the organization of scholarly fields. Further, if the results are to be useful, some of these collaborations should be less than obvious-that is, with fields outside the usual set of collaborators.

\section{Data Analysis}

All searches specified a research field and two topics. These were run in three ways: using the ProQuest-defined subject for both the field and the topics, using publication title for the field and abstracts for the topics, and using publication title for the field and full text for the topics. Co-occurrences were recorded in an adjacency matrix of the 16 topics. The value in any cell represented the number of distinct articles that include the research field and the two topics (topic $i$ and topic $j$ ). The searches were thus triadic but recorded in matrixes of dyads because the third search term, the research field, was reflected in the matrix itself.

The structure of topical attention was analyzed in two ways. The primary method had the purpose of determining the extent and significance of the correlations between research fields for a given mode of search (subject, abstract, or text). Because the data in each matrix are interdependent, the appropriate technique is quadratic assignment procedure (QAP). The QAP correlation routine in UCINET 6 (Borgatti, Everett, \& Freeman, 2002) was used, with 99,999 iterations to ensure stability in the results. QAP simulations generate significance levels for the correlations and thus measure the overall similarities of the structures of different fields. The fields are of different sizes, but QAP comparisons are unaffected by differences in scale (for an example, see Porac, Thomas, Wilson, Paton, \& Kanfer, 1995).

The secondary method had the purpose of finer-grained exploration of differences in

\section{Stewart}


topical attention, particularly regarding differences in attention to familial or business topics. It also allowed us to see if any topics might serve a framing function. To determine how prominent the nodes are in a network-in this case, the topics-the simplest and best tool is degree centrality (Wasserman \& Faust, 1994, p. 179). Although it is a simple calculation of the total co-occurrences of each topic with all other topics, it has the benefits of being transparent and of admitting the use of valued data (unlike most other centrality measures).

\section{Results}

Descriptive statistics and the results of the QAP correlations are reported in Table 3. Searching by subject approach, entrepreneurship is significantly like only strategy and three other business disciplines and just barely positively correlated with family business. Family business, by contrast, is significantly similar to five nonbusiness school fields, particularly history, as well as economics, finance, marketing, and strategy. For reasons noted above-the possible lack of fit for our needs and peculiar coding-we need to be cautious in interpreting subject-based searches. However, these results suggest the possibility that nonobvious collaborations might be more promising than the obvious ones.

Searching by abstracts, the most egregious finding is that entrepreneurship is an outlier and significantly similar only to finance and strategy and not to family business.

Entrepreneurship is, in terms of significant ties, the least central field. Law is decidedly the most central. Family business, as with subject searches, is significantly similar to more fields within and without business schools. Searching by document text, entrepreneurship is no longer an outlier. Only in these searches is it significantly similar to family business. Family business is again significantly similar to a range of fields, within and without the business school. Curiously, family and marital therapy is not significantly similar to family business in any of the three search modes. Apparently therapists' conversations about conflicts and emotions do not direct them much to sources within family businesses.

The patterns of significant similarities are expressed in graphical form in Figures 1A, 1B, and $1 \mathrm{C}$. In these sociograms, the coordinates for the fields are determined by nonmetric MDS (using KrackPlot 3.3) (Krackhardt, Blythe, \& McGrath, 1994). In all cases, the fit as measured by stress is good to very good. The lines represent only significant ties, with the thickness reflecting the significance level. Although these are only aids to comprehension, they demonstrate the split between fields that gravitate toward the familial or the commercial poles and those that are more balanced. The main difference between the three sociograms is that Figure $1 \mathrm{C}$ displays greater density due to the convergence of attention when the full documents are searched. 
The pattern of skewing toward one pole or the other is reflected in the degree centrality (total co-occurrences) of the eight familial topics divided by the degree centrality of the eight commercial topics (Table 4). By this measure, economics, family business, and public administration policy are quite balanced between the two poles. Finance and marketing are skewed toward the commercial pole, and entrepreneurship and strategic management even more strongly so. Anthropology, history, law, organizational behavior, psychology, and sociology are skewed toward the familial pole. Family and marital therapy are very highly skewed in this way. As expected, fields that are skewed to one pole or the other with the abstracts tend to be less skewed with the full texts.

Examining the rank order of topics between abstracts and full text (not shown for reasons of space) reveals one apparent instance of topical framing. In the entrepreneurship journals, private equity ranks second in centrality in the abstracts but falls to 10th place in the full text. Perhaps this suggests that less is known about this topic than its perceived importance would warrant. Alternatively, it might suggest that the topic is a framing device that legitimizes a study as truly belonging in the entrepreneurship field. The relative inattention in the literature to topics of interest to entrepreneurship (entrepreneurial opportunity and private equity are the two least noted topics) suggests a reason for the highly distinctive structure of attention in that field.

\section{Limitations}

As noted, all the comparisons across fields can be interpreted only in terms of the topics selected, and the topics themselves can be understood only in terms of the search words that were used. Purely metaphorical or otherwise misleading usage of the words likely remains in the findings, particularly, but not only, for kinship. In the case of kinship, however, it is also likely that the searches underestimated its centrality because of the many exclusions and omissions for that topic. Presumably, many of the articles that did have "AND NOT" terms for kinship and were thereby excluded also included legitimate references to kinship. As He (1999) noted, in word-based bibliometry, the value of the results hinges on the choices of words and terms. Further, these limitations are examples of other limitations of automated, large-sample studies such as this with their reliance on proxies rather than painstaking content analyses.

Moreover, this study fails to distinguish among the articles for their overall quality or their impact on research. It simply takes all articles in a large number of field journals as equal. This study is ahistorical and, unlike the study by Grégoire and colleagues (2006), fails to account for the dynamic character of research fields. It represents neither the changes in the past nor the trends that are emerging. Further, its conceptualization of topics of interest to entrepreneurship

\section{Stewart}


and family business is subject to obsolescence. As Adams warned with some poetic license (1988, p. 165), "the so-called traditional definition of what is central to a [discipline] or department is always passé once it becomes possible to utter it in one hundred words or less."

\section{Conclusion}

This study is but one exploratory voyage, urging researchers to venture out into the waters beyond their own fish scales, to borrow Campbell's (1969) metaphor. Specific findings ought to be regarded with caution. Still, the broad brush results are clear. In the most general sense, the results are consistent with a view of family business as a pluralistic arena for engaging important research questions, as opposed to a unique specialty with well-defined boundaries (Callon et al., 1983; Dogan, 1997; Meyer, 1991). More specifically, convenient collaborations such as family business and entrepreneurship are not necessarily the most fruitful. Similar conclusions apply to other linkages; for example, strategy will not always be the best source of collaborators for entrepreneurship (compare Baker \& Pollock, 2007). The most likely suspects for collaboration might not be the most fruitful; the most unlikely might be the best.

One sensible reaction to this finding would be to decide that the challenges of collaboration across disparate fields outweigh the possible benefits. For other scholars, the reaction might be to try to incorporate for themselves the knowledge of another field-a daunting task (Devons \& Gluckman, 1964, is a classic statement). For still other scholars, the reaction might be to seek out collaborators with different training. Of course, they would need to seek out those particular scholars who do share their topical interest; most would likely have other interests because all fields are heterogeneous. But how would they know if their particular research area was particularly suited to cross-disciplinary collaboration? The approach used in this study could be used by any scholar with access to ProQuest, or any such database, to answer this question. We have seen that literature reviews in themselves are not currently solving the problem of identifying the range of relevant scholarship.

All that is needed is a set of topical interests and a set of appropriate words for the search. Three examples follow. Consider first the topical convergence of kinship, private equity, and venturing (startups). Two of the three topics are relatively commercial so we would expect that business school researchers would pay the most attention. This proves true, as searching for the full-text co-occurrence of these topics, and standardizing for the size of the 14 fields, shows that the fields paying the most attention are family business first, with entrepreneurship second, strategy a distant third, and law fourth. Consider next a conjunction of interests more

\section{Stewart}


attuned to the familial dimension, namely, kinship, posterity, and succession. Not surprisingly, the most attentive fields are family business, anthropology, and history. Finally, consider the conjunction of interests, noted at the outset, of distrust, secrecy, and succession.

Entrepreneurship is only the sixth-most attentive field and strategy the eighth. The most attentive are, in order, family business, history, law, anthropology, public administration/policy, and sociology. Clearly, there will be projects for which the most convenient collaborators are the most appropriate. However, this is by no means necessarily so, and wider collaborations for some purposes are more promising.

\section{References}

Abbott, A. (1988). The system of professions. Chicago, IL: University of Chicago Press. Adams, H. (1988). The academic tribes (2nd ed.). Urbana, IL: University of Illinois Press.

Aldrich, H. E., \& Cliff, J. E. (2003). The pervasive effects of family on entrepreneurship: Toward a family embeddedness perspective. Journal of Business Venturing, 18(5), 573-596.

Anderson, A. R., Jack, S. L., \& Dodd, S. D. (2005). The role of family members in entrepreneurial networks: Beyond the boundaries of the family firm. Family Business Review, 18(2), 135-154.

Baker, T., \& Pollock, T. G. (2007). Making the marriage work: The benefits of strategy's takeover of entrepreneurship for strategic organization. Strategic Organization, 5(3), 297-312.

Barth, F. (1967). Economic spheres in Darfur. In R. Firth (Ed.), Themes in economic anthropology (pp. 149-174). London: Tavistock.

Bedeian, A. G. (2005). Crossing disciplinary boundaries: A epilogomenon for Lockett and McWilliams. Journal of Management Inquiry, 14(2), 151-155.

Bird, B., Welsch, H., Astrachan, J. H., \& Pistrui, D. (2002). Family business research: The evolution of an academic field. Family Business Review, 15(4), 337-350.

Borgatti, S. P., Everett, M. G., \& Freeman, L. C. (2002). UCINET 6 for Windows version 6.166. Natick, MA: Analytic Technologies.

Brockhaus, R. H. (1994). Entrepreneurship and family business research: Comparison, critique, and lessons. Entrepreneurship Theory and Practice, 19(1), 25-38.

Burt, R. S. (1992). Structural holes: The social structure of competition. Cambridge, MA: Harvard University Press.

Callon, M., Courtial, J.-P., Turner, W. A., \& Bauin, S. (1983). From translations to problematic networks: An introduction to co-word analysis. Social Science Information, 22(2), 
191-235.

Campbell, D. T. (1969). Ethnocentrism of disciplines and the fish-scale model of omniscience. In M. Sherif \& C. W. Sherif (Eds.), Interdisciplinary relationships in the social sciences (pp. 328-348). Chicago, IL: Aldine.

Carsten, J. (2000). Introduction. In J. Carsten (Ed.), Cultures of relatedness: New approaches to the study of kinship (pp. 1-36). Cambridge, UK: Cambridge University Press.

Casillas, J., \& Acedo, F. (2007). Evolution of the intellectual structure of family business literature: A bibliometric study of FBR. Family Business Review, 20(2), 141-162.

Comaroff, J. L. (1987). Sui genderis: Feminism, kinship theory and structural "domains." In J. F. Collier \& S. J. Yanagisako (Eds.), Gender and kinship: Essays toward a unified analysis (pp. 53-85). Stanford, CA: Stanford University Press.

Cornelius, B., Landström, H., \& Persson, O. (2006). Entrepreneurial studies: The dynamic research front of a developing social science. Entrepreneurship Theory and Practice, 30(3), 375-398.

Davis, M. S. (1971). That's interesting! Towards a phenomenology of sociology and a sociology of phenomenology. Philosophy of the Social Sciences, 1, 309-344.

Devons, E., \& Gluckman, M. (1964). Conclusion: Modes and consequences of limiting a field of study. In M. Gluckman (Ed.), Closed systems and open minds (pp. 158-261). Chicago, IL: Aldine.

Dogan, M. (1997). The new social sciences: Cracks in the disciplinary walls. International Social Science Journal, 49(3), 429-443.

Dyer, W. G., Jr. (2003). The family: The missing variable in organizational research. Entrepreneurship Theory and Practice, 27(4), 401-416.

Dyer, W. G., Jr., \& Handler, W. (1994). Entrepreneurship and family business: Exploring the connections. Entrepreneurship Theory and Practice, 19(1), 71-83.

Ellis, D., Allen, D., \& Wilson, T. (1999). Information science and information systems: Conjunct subjects disjunct disciplines. Journal of the American Society for Information Science, 50(12), 1095-1107.

Epstein, S. L. (2005). Making interdisciplinary collaboration work. In S. J. Derry. C. D. Schunn, \& M. A. Gernsbacher (Eds.), Inter disciplinary collaboration: An emerging cognitive Science (pp. 245-263). Mahwah, NJ: Erlbaum.

Fortes, M. (1969). Kinship and the social order: The legacy of Lewis Henry Morgan. Chicago, IL: Aldine.

Gartner, W. B., Davidsson, P., \& Zahra, S. A. (2006). Are you talking to me? The nature of

\section{Stewart}


community in entrepreneurship scholarship. Entrepreneurship Theory and Practice, 30(3), 321-331.

Grégoire, D. A., Noël, M. X., Déry, R., \& Béchard, J.-P. (2006). Is there conceptual convergence in entrepreneurship research? A co-citation analysis of Frontiers of Entrepreneurship Research, 1981-2004. Entrepreneurship Theory and Practice, 30(3), 333-373.

Griffiths, T. L., \& Steyvers, M. (2004). Finding scientific topics. Proceedings of the National Academy of Sciences, 101(Suppl. 1), 5228-5235.

Hambrick, D. C., \& Chen, M. J. (2008). New academic fields as admittance-seeking social movements: The case of strategic management. Academy of Management Review, 33(1), 32-54.

Hargens, L. L. (2000). Using the literature: Reference networks, reference contexts, and the social structure of scholarship. American Sociological Review, 65(6), 846-865.

Harrell, S. (1997). Human families. Boulder, CO: Westview.

He, Q. (1999). Knowledge discovery through co-word analysis. Library Trends, 48(1), 133-159.

Henkel, M. (2004). Current science policies and their implications for the formation and maintenance of academic identity. Higher Education Policy, 17(2), 167-182.

Holy, L. (1996). Anthropological perspectives on kinship theory. London: Pluto Press.

Hoy, F.,\& Verser, T. G. (1994). Emerging business, emerging field: Entrepreneurship and the family firm. Entrepreneurship Theory and Practice, 19(1), 9-23.

Jacobs, N. (2002). Co-term network analysis as a means of describing the information landscapes of knowledge communities across sectors. Journal of Documentation, 58(5), 548-562.

Jones, A. M. (2005). The elementary structures of the family firm: An anthropological perspective. Human Organization, 64(3), 276-285.

Kirzner, I. M. ([1997] 2000). Entrepreneurial discovery and the competitive market process: An Austrian approach. In I. M. Kirzner (Ed.), The driving force of the market (pp. 3-40). London: Routledge.

Klein, J. T. (2005). Interdisciplinary teamwork: The dynamics of collaboration and integration. In S. J. Derry, C. D. Schunn, \& M. A. Gernsbacher (Eds.), Interdisciplinary collaboration: An emerging cognitive science (pp. 23-50). Mahwah, NJ: Lawrence Erlbaum Associates.

Krackhardt, D., Blythe, J., \& McGrath, C. (1994). Krack-Plot 3.0: An improved network drawing program. Connections, 17(2), 53-55.

Lockett, A., \& McWilliams, A. (2005). The balance of trade between disciplines: Do we 
effectively manage knowledge? Journal of Management Inquiry, 14(2), 139-150.

Marcus, G. E., \& Hall, P. D. (1992). Lives in trust: The fortunes of dynastic families in late twentieth-century America. Boulder, CO: Westview Press.

McCarthy, A. M., \& Nicholls-Nixon, C. L. (2001). Fresh starts: Arnold Cooper on entrepreneurship and wealth creation. Academy of Management Executive, 15(1), 26-36.

McKinnon, S. (2000). Domestic exceptions: Evans-Pritchard and the creation of Nuer patrilineality and equality. Cultural Anthropology, 15(1), 35-83.

Meyer, A. D. (1991). What is strategy's distinctive competence? Journal of Management, 17(4), 821-833.

Miller, D.,\& Le Breton-Miller, I. (2005). Managing for the long run. Boston, MA: Harvard Business School Press.

Morillo, F., Bordons, M., \& Gómez, I. (2003). Interdisciplinarity in science: A tentative typology of disciplines and research areas. Journal of the American Society for Information Science and Technology, 54(13), 1237-1249.

National Science Foundation (NSF). (2006). Investing in America's future: Strategic plan, FY 2006-2111. Available at http://www.nsf.gov/pubs/2006/nsf0648/NSF-06-48.pdf.

Nicholson, N. (2008). Evolutionary psychology and family business; A new synthesis for theory, research, and practice. Family Business Review, 21(1), 103-124.

O’Donnell, A. M., \& Derry, S. J. (2005). Cognitive processes in interdisciplinary groups: Problems and possibilities. In S. J. Derry, C. D. Schunn, \& M. A. Gernsbacher (Eds.), Interdisciplinary collaboration: An emerging cognitive science (pp. 51-82). Mahwah, NJ: Lawrence Erlbaum Associates.

Pierce, S. J. (1999). Boundary crossing in research literatures as a means of interdisciplinary information transfer. Journal of the American Society for Information Science, 50(3), 271-279.

Porac, J. F., Thomas, H., Wilson, F., Paton, D., \& Kanfer, A. (1995). Rivalry and the industry model of Scottish knitwear producers. Administrative Science Quarterly, 40(2), 203-227.

Ramos-Rodríguez, A.-R., \& Ruíz-Navarro, J. (2004). Changes in the intellectual structure of strategic management research: A bibliometric study of the Strategic Management Journal, 1980-2000. Strategic Management Journal, 25(10), 981-1004.

Reader, D., \& Watkins, D. (2006). The social and collaborative nature of entrepreneurship scholarship: A co-citation and perceptual analysis. Entrepreneurship Theory and Practice, 30(3), 417-441. 
Schildt, H. A., Zahra, S. A., \& Sillanpää, A. (2006). Scholarly communities in entrepreneurship research: A co-citation analysis. Entrepreneurship Theory and Practice, 30(3), 399-415.

Sharma, P. (2004). An overview of the field of family business studies: Current status and directions for the future. Family Business Review, 17(1), 1-36.

Shugan, S. M. (2003). Editorial: Compartmentalized reviews and other initiatives: Should marketing scientists review manuscripts in consumer behavior? Marketing Science, 22(2), 151-160.

Slingerland, E. (2003). Effortless action: Wu-wei as conceptual metaphor and spiritual ideal in early China. New York: Oxford University Press.

Small, H. (1999). A passage through science: Crossing disciplinary boundaries. Library Trends, 48(1), 72-108.

Stewart, A. (1995). Journal ranking in Nacirema ritual: The case of I. C. MacMillan's publishing "forums." Advances in Strategic Management, 11(A), 3-37.

Stewart, A. (2003). Help one another, use one another: Toward an anthropology of family business. Entrepreneurship Theory and Practice, 27(4), 383-396.

Thagard, P. (2005). Being interdisciplinary: Trading zones in cognitive science. In S.J. Derry, C. D. Schunn, \& M. A. Gernsbacher (Eds.), Interdisciplinary collaboration: An emerging cognitive science (pp. 317-339). Mahwah, NJ: Lawrence Erlbaum Associates.

Teil, G., \& Latour, B. (1995). The Hume machine: Can association networks do more than formal rules? Stanford Humanities Review, 4(2), 47-65.

Wasserman, S., \& Faust, K. (1994). Social network analysis: Methods and applications. New York: Cambridge University Press.

Yanagisako, S. J. (1987). Mixed metaphors: Native and anthropological models of gender and kinship domains. In J. F. Collier \& S. J. Yanagisako (Eds.), Gender and kinship: Essays toward a unified analysis (pp. 86-118). Stanford, CA: Stanford University Press.

Zahra, S. A., \& Sharma, P. (2004). Family business research: A strategic reflection. Family Business Review, 17(4), 331-346.

Zald, M. N. (2002). Spinning disciplines: Critical management studies in the context of the transformation of management education. Organization, 9(3), 365-385.

Zerubavel, E. (1995). The rigid, the fuzzy, and the flexible: Notes on the mental sculpting of academic identity. Social Research, 62(4), 1093-1101.

\section{Notes}

- Alex Stewart, Coleman Foundation Chair in Entrepreneurship, Marquette University, 
Milwaukee, WI 53201-1881; tel (H): 414 906-8948; tel (O): 414 288-7188; fax: 414 288-1965; alex.stewart@mu.edu.

- This article is a revision of a manuscript presented at the 2008 Academy of Management Conference. Thanks are due to the Academy's and FBR's reviewers and to participants in the Management Department colloquia, Marquette University. 


\section{Appendix \\ Table 1 Search Terms for Topics}

\begin{tabular}{|c|c|}
\hline Affinity & $\begin{array}{l}\text { By Subject (S): Couples or Spouses or Husbands or Wives; By Abstract (A) or Document Text } \\
(T) \text { : affine* or in-law* or spouse* or husband* or wife or wives or conjugal or } \\
\text { copreneur* } N=203 \text { (S), } 1,395 \text { (A) } 178,356(T) \text {. }\end{array}$ \\
\hline Conflict & $\begin{array}{l}\text { S: Conflicts or Disputes; A or T: conflict* or disput* or dissent or dissension or faction* or } \\
\text { animosit* or antagonism* or rival }{ }^{*} N=256(\mathrm{~S}), 3,612 \text { (A), } 328,024 \text { (T) }\end{array}$ \\
\hline Distrust & $\begin{array}{l}\text { S: not possible; A or T: distrust* or leeriness or mistrust* or suspect* or suspicion* } N=N A \\
\text { (S), } 581 \text { (A) } 202,376(\mathrm{~T}) \text {. }\end{array}$ \\
\hline Emotion & $\begin{array}{l}\text { S: Emotions or Anger or Love or Jealousy; A or T: emotion* or anger or elat* or excite* or } \\
\text { grief or happiness or joy or passion or sadness or sorrow or thrill or zeal } N=368(\mathrm{~S}) \text {, } \\
1,999 \text { (A) } 225,745 \text { (T) }\end{array}$ \\
\hline Kinship & $\begin{array}{l}\text { S: "Extended families" or Families or Family or "Family members" or "Family relations" or } \\
\text { "parent-child relations" or "parents \& children" or siblings; A or T: kinship or sibling* or } \\
\text { mother* or father* or brother* or uncle* or aunt* or cousin* or daughter* or parent* } \\
\text { or sister* AND NOT "parent compan*" or "parent firm*" or "sister company* or "sister } \\
\text { firm*" or "corporate parent" or "founding father*" (sons not included because it } \\
\text { captures publishers such as Wiley and Sons) } N=1,030 \text { (S), } 3,191 \text { (A), } 311,338 \text { (T) }\end{array}$ \\
\hline $\begin{array}{l}\text { Posterity and Later } \\
\text { Generations }\end{array}$ & 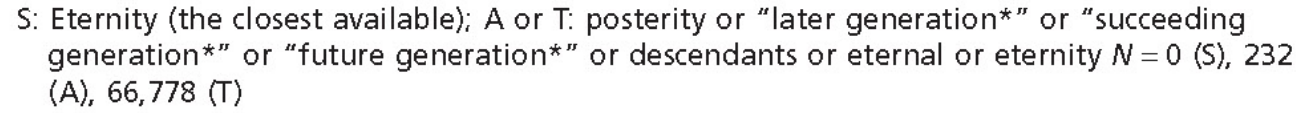 \\
\hline Secrecy & $\begin{array}{l}\text { S: Secrecy or Secret; A or T: secre* or "in confidence" or confidential* or conspira* or } \\
\text { privacy or covert* or seclu* or undisclosed or surreptitious* or disguise* or "information } \\
\text { asymmetr*" } N=9 \text { (S), } 1,672 \text { (A), } 310,944 \text { (T) }\end{array}$ \\
\hline $\begin{array}{l}\text { Succession and } \\
\text { Inheritance }\end{array}$ & $\begin{array}{l}\text { S: Inheritance or "Inheritance \& Succession" or Successors; A or T: succession or estate or } \\
\text { successor* or "taking over" or inherit* or heir* } N=76 \text { (S), 1,703 }(A), 193,047 \text { (T) }\end{array}$ \\
\hline Alertness & $\begin{array}{l}\text { S: Alert or Perception; A or T: alert* or attentive* or observant or perceptive } N=416 \text { (S), } \\
195 \text { (A), } 76,812 \text { (T) }\end{array}$ \\
\hline Brokerage & $\begin{array}{l}\text { S: Arbitrage or "Business Networking"; A or T: arbitrag* or broker* or betweenness or } \\
\text { "structural hole*" or "sphere* of exchange" or intermediar* or intermediation } N=56 \\
\begin{array}{ll}\text { (S), } 1,143 \text { (A), } 131,164 \text { (T) }\end{array}\end{array}$ \\
\hline $\begin{array}{c}\text { Entrepreneurial } \\
\text { Opportunity }\end{array}$ & $\begin{array}{l}\text { S: Opportunities or "Business Growth"; A or T: "wealth creation" or "creation of wealth" } \\
\text { or "new wealth" or "Wealth accumulation" or "accumulate weal th" or "business } \\
\text { opportunit*" or "entrepreneurial opportunit*" } N=255 \text { (S), } 188 \text { (A), } 21,137 \text { (T) }\end{array}$ \\
\hline Innovation & $\begin{array}{l}\text { S: Creativity or "Innovation" or "Innovation in Business"; A or T: creativ* or innovate* or } \\
\text { invent* or visionary or imaginative or ingenious } N=418 \text { (S), } 2,156 \text { (A), } 232,963 \text { (T) }\end{array}$ \\
\hline Planning & S: Plans or Planning; A or T: plan or plans or planning $N=1,182(\mathrm{~S}), 6,669$ (A), 307,918 (T) \\
\hline Private Equity & $\begin{array}{l}\text { S: "Angel Investors" or "Private Equity" or "Private Equity Funds" or "Private Financial } \\
\text { Support" or "Venture Capital" or "Venture Capital Companies" or "Venture Capital } \\
\text { Industry"; A or T: "private equity" or "private placement" or "angel invest*" or "venture } \\
\text { capital*" or "term sheet*" or "business angel*" } N=178 \text { (S), } 369 \text { (A), 18,242 (T) }\end{array}$ \\
\hline Profit & $\begin{array}{l}\text { S: "Cash flow" or "Economic rent" or "net income" or profits or profitability or solvency; A } \\
\text { or T: profit* or "cash flow" or "economic rent*" or solven* } N=298(\mathrm{~S}), 3,342 \text { (A), } \\
232,098(\mathrm{~T})\end{array}$ \\
\hline Venturing & $\begin{array}{l}\text { S: "New Business" or Startups; A or T: venturing or "new venture*" or "venture creation" } \\
\text { or startup* or start-up* or founding or founder } N=255 \text { (S), 1,265 (A), } 172,244 \text { (T) }\end{array}$ \\
\hline
\end{tabular}




\section{Table 2 Search Terms for Fields of Study}

\begin{tabular}{|c|c|}
\hline Anthropology & $\begin{array}{l}\text { By Subject }(S) \text { : Anthropology or Ethnology }(N=30,379) \text {; By Publication Title }(P) \text { : } \\
\text { Anthropolog* or ethnolog* or "Human Organization" AND NOT "Sociology and } \\
\text { Anthropology" }(N=24,702)\end{array}$ \\
\hline Economics & $\begin{array}{l}\text { S: Economics }(N=38,853) \text {; P: Economic* AND NOT Law or "Financial Economics" } \\
(N=198,283)\end{array}$ \\
\hline Entrepreneurship & $\begin{array}{l}\text { S: Entrepreneurs or "New business" }(N=7,662) \text {; P: Entrepreneur* or Venturing } \\
(N=3,251)\end{array}$ \\
\hline Family Business & S: "Family owned businesses" ( $N=851)$; P: "Family business*" $(N=325)$ \\
\hline $\begin{array}{l}\text { Family and Marital } \\
\text { Therapy }\end{array}$ & $\begin{array}{l}\text { S: "Family counseling" or "Family therapy" or "marital counseling" or "Marital } \\
\text { therapy" }(N=1,995) \text {; } \mathrm{P} \text { : "Family therap*" or "family counsel*" or "marriage } \\
\text { therap*" or "marriage counsel*" or "marital therap*" or "marital counsel*" } \\
(N=3,145)\end{array}$ \\
\hline Finance & S: Finance $(N=13,230) ;$ P: Financ* AND NOT Law or legal $(N=66,469)$ \\
\hline History & $\begin{array}{l}\text { S: History ( } N=286,810) \text {; P: Histor* or "American Quarterly" or "Eighteenth Century } \\
\text { Studies" or "Past \& Present" or "Victorian Studies" or "William and Mary } \\
\text { Quarterly" }(N=220,539)\end{array}$ \\
\hline Law & $\begin{array}{l}\text { S: Law or "Law \& legal issues" }(N=61,930) \text {; P: Law or legal AND NOT Economic* or } \\
\text { Financ* }(N=99,319)\end{array}$ \\
\hline Marketing & S: Marketing $(N=17,593)$; P: Marketing or "Consumer Research" $(N=52,370)$ \\
\hline Organizational Behavior & S: "Organizational Behavior" $(N=21,734)$; P: "organizational behavior" $(N=4,709)$ \\
\hline Psychology & S: Psychology $(N=68,130) ;$ P: Psycholog* $(N=95,811)$ \\
\hline $\begin{array}{l}\text { Public Administration } \\
\text { \& Public Policy }\end{array}$ & $\begin{array}{l}\text { S: "Public administration" or "Public policy" }(N=20,072) \text {; P: "Public administrat*" or } \\
\text { "public polic*" }(N=18,995)\end{array}$ \\
\hline Sociology & $\begin{array}{l}\text { S: Sociology }(N=22,003) \text {; P: Sociolog* or "Social Forces" AND NOT "Sociology and } \\
\text { Anthropology" }(N=41,317)\end{array}$ \\
\hline Strategic Management & $\begin{array}{l}\text { S: "Strategic management" }(N=7,113) \text {; P: "business strateg*" or "strategic } \\
\text { management" AND NOT "small business strateg*" }(N=9,664)\end{array}$ \\
\hline
\end{tabular}


Table 3 Descriptive Statistics and Pearson Correlation Coefficients (QAP)

\begin{tabular}{|c|c|c|c|c|c|c|c|c|c|c|c|c|c|c|c|c|c|}
\hline \multicolumn{18}{|c|}{ By Subject } \\
\hline & $\begin{array}{l}\text { Field of } \\
\text { Study }\end{array}$ & $\begin{array}{l}\mathrm{N} \\
\text { (Articles) }\end{array}$ & Mean & SD & 1 & 2 & 3 & 4 & 5 & 6 & 7 & 8 & 9 & 10 & 11 & 12 & 13 \\
\hline 1 & Anthro. & 34,141 & 0.22 & 0.97 & & & & & & & & & & & & & \\
\hline 2 & Econ. & 61,041 & 0.79 & 2.85 & $0.44^{*}$ & & & & & & & & & & & & \\
\hline 3 & Entrep. & 8,181 & 3.60 & 9.15 & 0.01 & 0.24 & & & & & & & & & & & \\
\hline 4 & Fam. Bus. & 1,028 & 2.66 & 19.58 & $0.70^{* * *}$ & $0.60^{*}$ & 0.08 & & & & & & & & & & \\
\hline 5 & Fam-Marr & 2,167 & 1.32 & 6.65 & $0.40^{*}$ & 0.02 & -0.06 & 0.04 & & & & & & & & & \\
\hline 6 & Finance & 17,796 & 1.13 & 3.08 & $0.29^{*}$ & $0.73 * * *$ & $0.62^{* *}$ & $0.39 *$ & 0.06 & & & & & & & & \\
\hline 7 & History & 302,077 & 1.44 & 5.42 & $0.69 * *$ & $0.82 * * *$ & 0.21 & $0.89 * *$ & 0.12 & $0.64 * *$ & & & & & & & \\
\hline 8 & Law & 74,380 & 1.45 & 4.88 & $0.63 * *$ & $0.52 * *$ & 0.08 & $0.66 * *$ & $0.56 *$ & $0.42^{*}$ & $0.72 * *$ & & & & & & \\
\hline 9 & Marketing & 18,626 & 1.70 & 7.79 & 0.08 & $0.83 * * *$ & $0.31 *$ & 0.15 & -0.01 & $0.70^{* *}$ & $0.50^{*}$ & $0.21 *$ & & & & & \\
\hline 10 & Org. Beh. & 23,587 & 3.11 & 9.26 & 0.09 & $0.50^{*}$ & $0.38^{*}$ & 0.07 & 0.06 & $0.35^{*}$ & $0.33^{*}$ & 0.19 & $0.67^{* *}$ & & & & \\
\hline 11 & Psych. & 119,887 & 4.19 & 16.65 & $0.32 *$ & 0.04 & -0.08 & 0.06 & $0.38^{*}$ & -0.02 & 0.14 & 0.18 & -0.01 & 0.13 & & & \\
\hline 12 & Pub. Ad./Pol. & 28,871 & 0.90 & 4.54 & $0.67 * *$ & $0.64 * *$ & 0.25 & $0.89 * *$ & 0.06 & $0.43^{*}$ & $0.86 * *$ & $0.64 * *$ & $0.31^{*}$ & $0.46^{*}$ & 0.06 & & \\
\hline 13 & Soc. & 25,001 & 0.33 & 1.26 & $0.72 * *$ & $0.37^{*}$ & -0.01 & $0.64 * *$ & $0.46^{*}$ & 0.26 & $0.64 * *$ & $0.56 * *$ & 0.09 & 0.12 & $0.55^{* *}$ & $0.58 * *$ & \\
\hline 14 & Strategy & 8,020 & 0.91 & 3.55 & $0.24^{*}$ & $0.46^{*}$ & $0.48^{*}$ & $0.36 *$ & -0.03 & $0.26^{*}$ & $0.45^{*}$ & $0.26 *$ & $0.42 *$ & $0.77^{* *}$ & -0.01 & $0.66^{*}$ & 0.19 \\
\hline \multicolumn{18}{|c|}{ By Abstract } \\
\hline 1 & Anthro. & 24,702 & 1.51 & 3.89 & & & & & & & & & & & & & \\
\hline 2 & Econ. & 198,283 & 24.13 & 55.47 & 0.13 & & & & & & & & & & & & \\
\hline 3 & Entrep. & 3,251 & 2.83 & 7.56 & -0.03 & 0.15 & & & & & & & & & & & \\
\hline 4 & Fam. Bus. & 325 & 0.54 & 1.81 & 0.14 & 0.11 & 0.18 & & & & & & & & & & \\
\hline 5 & Fam-Marr & 3,145 & 0.98 & 3.31 & $0.86 * * *$ & 0.05 & -0.03 & 0.01 & & & & & & & & & \\
\hline 6 & Finance & 66,469 & 17.90 & 38.78 & -0.07 & $0.62 * *$ & $0.27^{*}$ & $0.47 * *$ & -0.10 & & & & & & & & \\
\hline 7 & History & 220,539 & 10.91 & 17.51 & $0.87 * * *$ & 0.21 & -0.02 & 0.18 & $0.70^{* * *}$ & -0.01 & & & & & & & \\
\hline 8 & Law & 99,319 & 20.02 & 34.49 & $0.60 * *$ & $0.36^{*}$ & -0.01 & $0.35^{*}$ & $0.40^{*}$ & 0.19 & $0.71 * * *$ & & & & & & \\
\hline 9 & Marketing & 52,370 & 7.21 & 19.68 & 0.06 & $0.82 * * *$ & 0.13 & 0.06 & 0.01 & $0.58^{* * *}$ & 0.12 & $0.27^{*}$ & & & & & \\
\hline 10 & Org. Beh. & 4,709 & 0.76 & 2.07 & $0.46^{*}$ & 0.25 & -0.05 & 0.03 & $0.39 *$ & 0.07 & $0.31 *$ & $0.45^{* *}$ & $0.30^{*}$ & & & & \\
\hline 11 & Psych. & 95,811 & 15.78 & 59.65 & $0.64 * *$ & 0.05 & -0.02 & 0.01 & $0.86 * * *$ & -0.07 & $0.48^{* *}$ & $0.34^{*}$ & 0.07 & $0.53 * *$ & & & \\
\hline 12 & Pub. Ad./Pol. & 18,995 & 2.00 & 5.24 & 0.18 & $0.52 * *$ & 0.03 & $0.26^{*}$ & 0.01 & $0.28^{*}$ & 0.25 & $0.54 * *$ & $0.59 * *$ & $0.30^{*}$ & 0.08 & & \\
\hline 13 & Soc. & 41,317 & 3.44 & 7.26 & $0.79 * * *$ & 0.20 & 0.19 & $0.30^{*}$ & $0.71 * * *$ & 0.21 & $0.67 * * *$ & $0.53 * *$ & 0.15 & $0.42 * *$ & $0.60^{* * *}$ & 0.26 & \\
\hline 14 & Strategy & 9,664 & 3.26 & 8.49 & -0.01 & $0.76 * * *$ & $0.30^{*}$ & $0.33^{*}$ & -0.08 & $0.65 * * *$ & 0.05 & 0.24 & $0.91 * * *$ & 0.18 & -0.02 & $0.63 * *$ & 0.17 \\
\hline \multicolumn{18}{|c|}{ By Document Text } \\
\hline 1 & Anthro. & 24,702 & 621.9 & 544.1 & & & & & & & & & & & & & \\
\hline 2 & Econ. & 198,283 & $1,799.7$ & $1,815.7$ & $0.59 * *$ & & & & & & & & & & & & \\
\hline 3 & Entrep. & 3,251 & 98.3 & 94.3 & 0.19 & $0.65 * *$ & & & & & & & & & & & \\
\hline 4 & Fam. Bus. & 325 & 32.4 & 28.0 & $0.47^{*}$ & $0.61 * *$ & $0.64 * *$ & & & & & & & & & & \\
\hline 5 & Fam-Marr & 3,145 & 61.9 & 97.2 & $0.79 * * *$ & 0.30 & 0.09 & 0.27 & & & & & & & & & \\
\hline 6 & Finance & 66,469 & $854.2 \quad 1$ & $1,081.7$ & 0.19 & $0.57 * *$ & $0.67 * * *$ & $0.60 * *$ & 0.02 & & & & & & & & \\
\hline 7 & History & 220,539 & $3,233.8 \quad 3$ & $3,018.4$ & $0.81 * * *$ & $0.55^{* *}$ & 0.16 & 0.35 & $0.63^{* *}$ & 0.18 & & & & & & & \\
\hline 8 & Law & 99,319 & $2,807.9 \quad 2$ & $2,666.0$ & $0.83 * * *$ & $0.68^{* *}$ & 0.29 & $0.47^{*}$ & $0.71 * * *$ & 0.28 & $0.87^{* * *}$ & & & & & & \\
\hline 9 & Marketing & 52,370 & 909.21 & $1,148.0$ & $0.53 * *$ & $0.85 * * *$ & $0.66 * *$ & $0.51 *$ & $0.44^{*}$ & $0.54 * *$ & $0.46 * *$ & $0.60 * *$ & & & & & \\
\hline 10 & Org. Beh. & 4,709 & 52.2 & 66.2 & $0.77 * * *$ & $0.55 * *$ & 0.30 & $0.34^{*}$ & $0.82^{* * * *}$ & 0.26 & $0.69 * * *$ & $0.77^{* * *}$ & $0.68 * *$ & & & & \\
\hline 11 & Psych. & 95,811 & $\begin{array}{ll}781.6 \quad 1 \\
\end{array}$ & $1,204.1$ & $0.81 * * *$ & $0.39 *$ & 0.19 & 0.34 & $0.89 * * *$ & 0.12 & $0.61 * *$ & $0.65 * *$ & $0.59 * *$ & $0.87 * * *$ & & & \\
\hline 12 & Pub. Ad./Pol. & 18,995 & 375.4 & 508.9 & $0.50 * *$ & $0.61 * *$ & $0.62 * *$ & $0.49 * *$ & $0.40^{*}$ & $0.63 * * *$ & $0.52 * *$ & $0.63 * * *$ & $0.60 * *$ & $0.55^{* *}$ & $0.44^{*}$ & & \\
\hline 13 & Soc. & 41,317 & 706.7 & 776.6 & $0.63 * *$ & $0.47^{*}$ & 0.51 ** & $0.69 * * *$ & $0.54 * *$ & $0.55 * *$ & $0.49 * *$ & $0.61 * *$ & $0.49^{*}$ & $0.59 * *$ & $0.58^{* *}$ & $0.71 * * *$ & \\
\hline 14 & Strategy & 9,664 & 191.0 & 244.2 & 0.33 & $0.84 * * *$ & $0.84 * * *$ & $0.58 * *$ & 0.19 & $0.63 * *$ & 0.30 & $0.47^{*}$ & $0.87 * * *$ & $0.49 * *$ & 0.32 & $0.66 * * *$ & $0.51 * *$ \\
\hline
\end{tabular}


Table 4 Familial-Commercial Ratios for 14 Fields*

\begin{tabular}{llcl}
\hline Field & By Subject & By Abstract & By Full Text \\
\hline Anthropology & 2.61 & 6.08 & 2.02 \\
Economics & 0.37 & 0.59 & 1.07 \\
Entrepreneurship & 0.06 & 0.27 & 0.61 \\
Family Business & 1.18 & 1.57 & 1.31 \\
Family/Marital Ther. & 8.48 & 11.67 & 2.90 \\
Finance & 0.28 & 0.39 & 0.71 \\
History & 0.82 & 3.14 & 2.20 \\
Law & 2.17 & 2.57 & 1.90 \\
Marketing & 0.10 & 0.44 & 0.91 \\
Organ. Behavior & 0.38 & 2.25 & 1.65 \\
Psychology & 2.51 & 5.63 & 2.32 \\
Public Ad./Policy & 0.61 & 0.94 & 1.05 \\
Sociology & 1.93 & 1.93 & 1.45 \\
Strategic Management & 0.13 & 0.30 & 0.68 \\
\hline
\end{tabular}

* Numbers over 1 imply a skewing to the familial and under 1 a skewing to the commercial: sum of co-occurrences for familial topics (Affines, Conflict, Distrust, Emotion, Kinship, Posterity, Secrecy, and Succession) divided by sum of co-occurrence for commercial topics (Alertness, Brokerage, Creativity, Entrepreneurial Opportunity, Planning, Private Equity, Profit, and Venturing). Figures for Subject searches are corrected for the absence of Distrust. 
Figure 1A Subject Searches

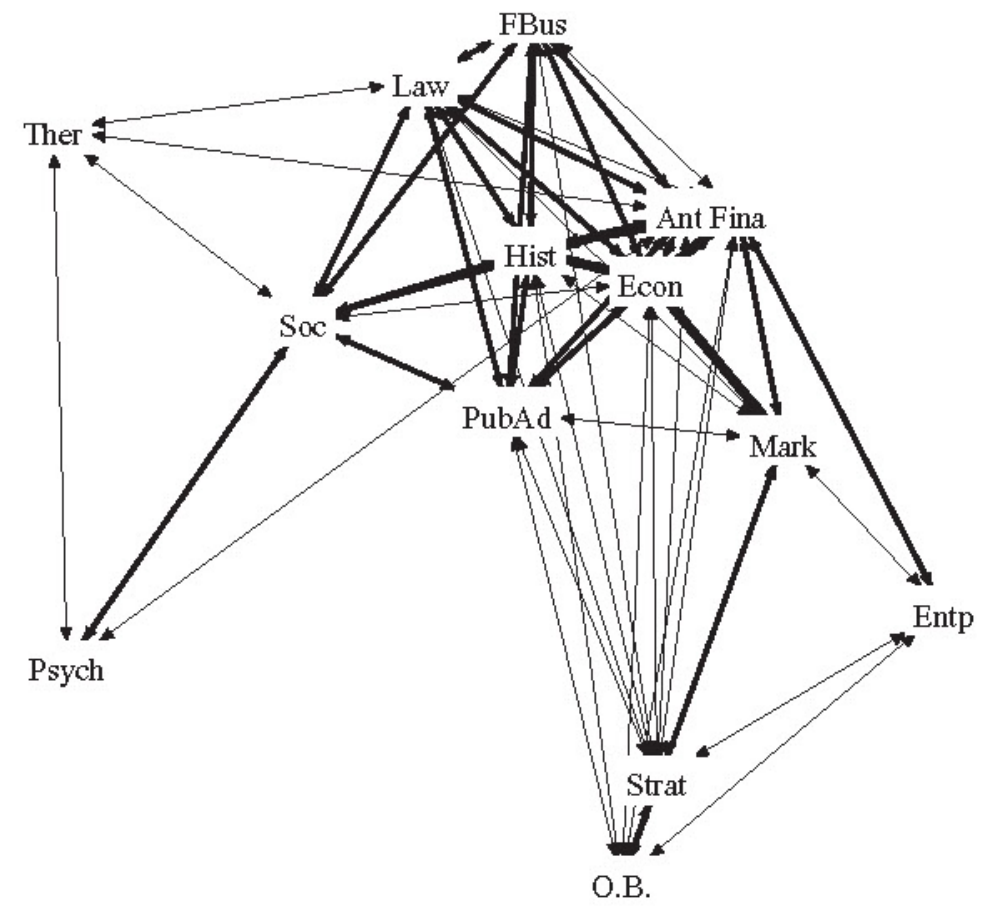

Coordinates by nonmetric MDS, stress $=0.113$ in 19 iterations.

Line thickness by significance: thickest $p<0.001$, medium $p<0.01$, thinnest $p<0.05$. 
Figure 1B Abstract Searches

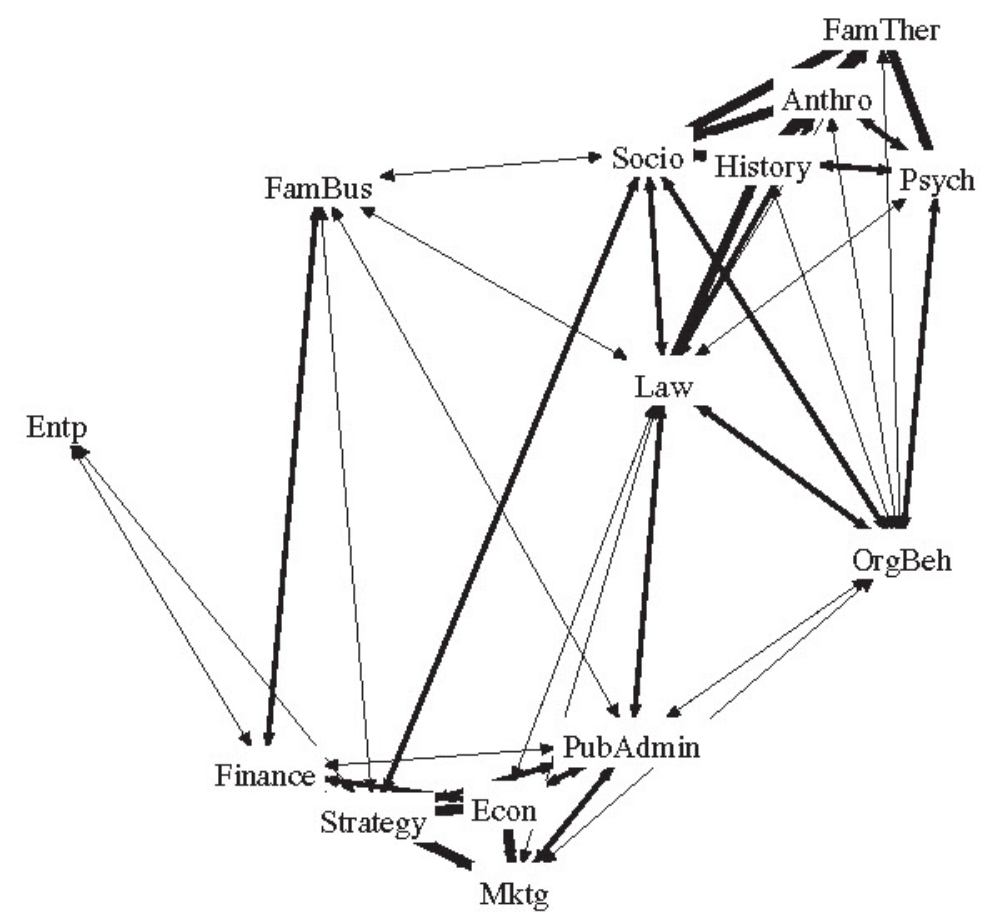

Coordinates by nonmetric MDS of complete correlation matrix, stress $=0.099$ in 11 iterations. Line thickness by significance: thickest $p<0.001$, medium $p<0.01$, thinnest $p<0.05$. 
Figure 1C Document Text Searches

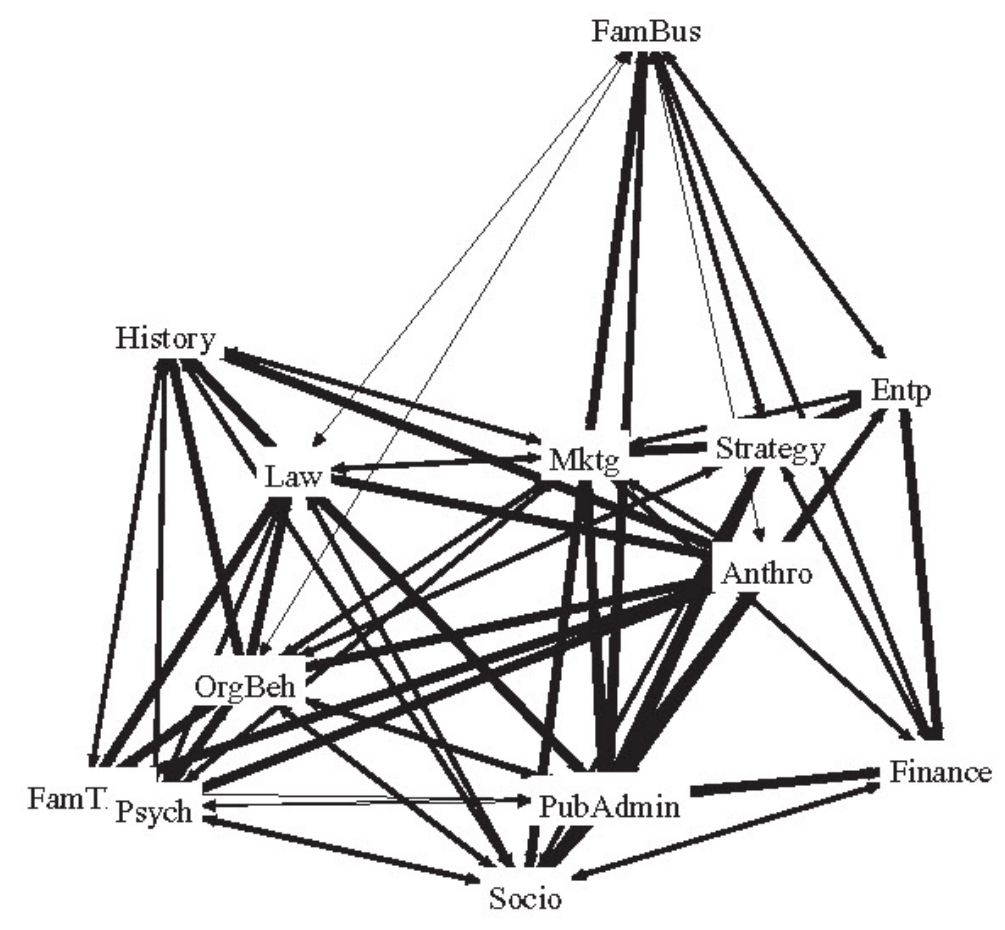

Coordinates by nonmetric MDS of complete correlation matrix, stress $=0.123$ in 16 iterations . Line thickness by significance: thickest $p<0.001$, medium $p<0.01$, thinnest $p<0.05$. 